\title{
Micropulse trans-scleral cyclophotocoagulation: treatment outcomes of refractory glaucoma in Malaysia
}

Liu Chee Chung ${ }^{1,2}$, Guhanesh Pappanayakann ${ }^{1,2}$, Ch'ng Tun Wang ${ }^{2}$, Thayanithi K. Sandragasu' ${ }^{2}$, Jelinar Mohamed Noor ${ }^{2}$, Nurliza Khaliddin ${ }^{1}$, Gan Eng Hui

${ }^{1}$ University of Malaya, Jalan Universiti, Kuala Lumpur, Malaysia; ${ }^{2}$ Hospital Kuala Lumpur, Jalan Pahang, Kuala Lumpur, Malaysia

\section{Abstract}

Introduction: A more novel form of cycloablation, micropulse cyclophotocoagulation (MPCPC), has gained popularity in recent years due to its proven efficacy in lowering intraocular pressure (IOP) as well as higher safety profile compared to conventional trans-scleral cyclophotocoagulation.

Purpose: The aim of this study was to investigate the treatment outcome of MPCPC as an adjunctive treatment for refractory glaucoma.

Study design: Retrospective interventional case series.

Materials and methods: Subjects were patients with refractory glaucoma and glaucoma progression; with or without prior glaucoma surgery, who were not keen or not suitable for glaucoma surgery. Outcomes were IOP-lowering effect and reduction of glaucoma medications at 6 months follow-up. Treatment success was defined as either achieving IOP $<21 \mathrm{mmHg}$ or IOP reduction of $20 \%$ from baseline IOP.

Results: The median age of patients was 57.5 years. A total of 34 eyes of 24 patients were treated with MPCPC with a mean follow-up period of 6 months. The majority of our patients $(79 \%)$ experienced mild to moderate pain during the procedure. The median IOP prior to MPCPC was $30 \mathrm{mmHg}$ and was significantly reduced at 1 week (17.5 mmHg), 1 month (17.5 mmHg), 3 months $(21.0 \mathrm{mmHg})$, and 6 months $(21.0 \mathrm{mmHg})$, with a $19.2 \%$ IOP reduction at the last follow-up. There were no

Correspondence: Liu Chee Chung, MBBS, B1901 Lorong Air Putih 21, 25300 Kuantan, Pahang, Malaysia.

E-mail:arspata@gmail.com 
cases of hypotony. The reduction in the number of glaucoma medications was not statistically significant. Our treatment success rate after a mean of 1.1 treatment sessions was $53 \%$ (16 out of 34 eyes).

Conclusions: Our study showed that MPCPC offers good IOP-lowering efficacy and patient tolerability in the treatment of refractory glaucoma. Larger, prospective, comparative studies are needed to determine a standardized MPCPC treatment protocol with high success and low complication rates.

Keywords: cyclophotocoagulation, glaucoma, intraocular pressure, laser, micropulse

\section{Sitokoagulasi transkleral mikropal: hasil rawatan glaukoma refraktori di Malaysia}

\section{Abstrak}

Pendahuluan: Satu bentuk sikloablasi yang baru, siklofotokoagulasi mikropal (MPCPC), telah mendapat populariti dalam beberapa tahun kebelakangan ini kerana keberkesanannya yang terbukti dalam menurunkan tekanan intraokular (IOP) serta profil keselamatan yang lebih tinggi berbanding dengan siklofotokoagulasi trans-scleral konvensional.

Tujuan: Tujuan kajian ini adalah untuk menyiasat hasil rawatan MPCPC sebagai rawatan tambahan untuk glaukoma refraktori.

Reka bentuk kajian: Rangkaian kes intervensi retrospektif.

Bahan dan kaedah: Subjek adalah pesakit dengan glaukoma refraktori dan glaucoma melarat; samada dengan atau tanpa pembedahan glaukoma sebelumnya, yang mana mereka tidak berminat atau tidak sesuai untuk pembedahan glaukoma. Dapatannya adalah kesan penurunan IOP dan pengurangan ubat glaukoma pada tarikh susulan 6 bulan. Kejayaan rawatan ditakrifkan sebagai mencapai IOP $<21$ mmHg atau penurunan IOP sebanyak $20 \%$ dari IOP awal.

Dapatan: Umur median pesakit adalah 57.5 tahun. Sebanyak 34 mata daripada 24 pesakit dirawat dengan MPCPC dengan min rawatan susulan selama 6 bulan. Sebilangan besar pesakit kami (79\%) mengalami kesakitan ringan hingga sederhana semasa prosedur. IOP median sebelum MPCPC adalah $30 \mathrm{mmHg}$ dan dikurangkan dengan ketara pada 1 minggu (17.5 $\mathrm{mmHg}), 1$ bulan $(17.5 \mathrm{mmHg})$, 3 bulan $(21.0 \mathrm{mmHg}$ ), dan 6 bulan $(21.0 \mathrm{mmHg})$, dengan pengurangan IOP 19.2\% pada susulan terakhir. Tidak ada kes hipotoni. Pengurangan jumlah ubat glaukoma tidak signifikan secara statistik. Tahap kejayaan rawatan kami selepas min 1.1 sesi rawatan adalah 53\% (16 dari 34 mata). 
Kesimpulan: Kajian kami menunjukkan bahawa MPCPC menawarkan keberkesanan penuruanan IOP yang baik dan toleransi pesakit dalam rawatan glaukoma refraktori. Kajian perbandingan yang lebih besar, prospektif, diperlukan untuk menentukan protokol rawatan MPCPC standard supaya mencapai tahap kejayaan yang tinggi dan tahap komplikasi yang rendah.

Kata kunci: glaukoma, laser, mikropal, siklofotokoagulasi, tekanan intraokular

\section{Introduction}

Glaucoma remains the leading cause of irreversible blindness in the world. ${ }^{1}$ Conventionally, it is managed in a stepwise algorithm, beginning with medications, laser, and lastly, surgery. Intraocular pressure (IOP) is the only current modifiable risk factor in glaucoma and lowering IOP remains the primary aim for all treatment modalities. Recently, laser in glaucoma management has undergone numerous advancements with modern techniques and alternative applications developed. Refined laser modalities have led to an expansion in the role of laser in glaucoma treatments with a trend towards utilizing them in the earlier course of the disease.

Trans-scleral cyclophotocoagulation (TSCPC) with continuous wave (CW) diode laser has been conventionally used in treating refractory glaucoma. It delivers CW of high-intensity energy to the pars plicata, causing destruction of the ciliary body, thus reducing the aqueous production and lowering IOP. ${ }^{2}$ However, complications such as hypotony, visual deterioration, phthisis bulbi, and unpredictable effects frequently occur. ${ }^{3}$ A more novel form of cycloablation, micropulse cyclophotocoagulation (MPCPC), has gained popularity in recent years due to its proven efficacy in lowering IOP with a higher safety profile compared to conventional TSCPC., MPCPC divides continuous-wave laser beam into periodic short pulses ("on" pulses), followed by "off" intervals. Each laser pulse heats up the pars plana of the ciliary body. The "off" intervals between each pulse allow thermal relaxation, thus reducing thermal buildup in tissues. The above mechanism results in targeted tissue damage and minimal collateral thermal burn to adjacent tissues, consequently reducing adverse effects. ${ }^{6}$

Our study describes the use of MPCPC in our center as an adjunctive treatment modality for refractory glaucoma. The primary treatment outcome was IOP reduction. Secondary outcomes were the pain score as reported by the subjects and the reduction in the number of glaucoma eye drops after the treatment. 


\section{Materials and methods}

This is a retrospective, non-comparative, interventional case series of patients with uncontrolled glaucoma seen in the glaucoma clinic of Hospital Kuala Lumpur, Malaysia. All subjects were treated with MPCPC and recruited between January 1 to June 30, 2017. The study was conducted in accordance with the principles of the Declaration of Helsinki. Given this was a retrospective study, no ethics approval was required from the institutional review board.

The inclusion criteria were patients with refractory glaucoma (not achieving target IOP on maximally tolerated medications) and those with glaucoma progression; with or without prior glaucoma surgery and who were not keen or not suitable for glaucoma surgery.

The exclusion criteria were patients with significant scleral thinning and those who had undergone intraocular surgery within 2 months of enrolment.

MPCPC was performed by two surgeons. Sub-Tenon local anesthesia of 1.5 $\mathrm{ml}$ lignocaine $2 \%$ and $1.5 \mathrm{ml}$ bupivacaine $0.5 \%$ were administered. A Cyclo $\mathrm{G}^{\mathrm{TM}}$ Glaucoma Laser System (Iridex Corp., Mountain View, CA, USA) was used in this study. The diode laser contact probe (Micropulse P $3^{\mathrm{TM}}$, Iridex) was held perpendicular to the limbal surface. The probe is designed such that the laser tip is positioned $3 \mathrm{~mm}$ posterior to the limbus. The laser was applied in continuous painting fashion: in an arc motion, to and fro over $360^{\circ}$ for 100 seconds ( 50 seconds for each semicircle). The 3- and 9-o'clock meridians of limbus, thinned sclera area, area of previous trabeculectomy, or drainage device site were avoided during the laser application. The settings used were $2000 \mathrm{~mW}$ of energy, 0.5 milliseconds "on"/1.1 milliseconds "off" (31.3\% duty cycle), with a maximum total energy level of $62.6 \mathrm{~J}$. The amount of energy in Joules $(\mathrm{J})=$ power in Watts $(\mathrm{W}) \times$ total treatment duration in seconds (s) x "on" cycle (31.3\%).

Data collected prior to treatment were age, gender, race, laterality of eyes, glaucoma type, previous ocular surgery history, glaucoma medications, and IOP (measured using Goldman applanation tonometer).

During the treatment procedure, pain experienced by patients was documented using the Numerical Rating Scale (NRS). Pain score was categorized into no pain (0), mild (1-3), moderate (4-6), and severe (7-10). ${ }^{7}$ After the procedure, all patients were given paracetamol for analgesia and gutt dexamethasone $0.5 \%$ every 4 hours for 1 week and tapered off over a month. All pre-procedure glaucoma eye drops were continued. Follow-up reviews were done at 1 week, 1 month, 3 months, and 6 months after the procedure. At each review, visual acuity, anterior segment examination, optic nerve examination and IOP were recorded. All IOPS were measured using the Goldmann applanation tonometer (GAT, Haag-Streit Diagnostics, Koeniz, Switzerland) by trained medical officers or specialists. The IOP-lowering medications were adjusted according to IOP response at follow-up. If the IOP was less than $21 \mathrm{mmHg}$ post-MPCPC, medications were reduced in a 
stepwise method. If it remained high ( $>21 \mathrm{mmHg}$ ), a second MPCPC treatment or glaucoma surgery was offered. Outcome measures were IOP-lowering effect and reduction in the number of glaucoma medications. Treatment success was defined as either achieving IOP $<21 \mathrm{mmHg}$ or IOP reduction of $20 \%$ from baseline IOP at 6 months.

Continuous variables were checked for normality using numerical and graphical methods. Non-parametric data (age in years and IOP in $\mathrm{mmHg}$ ) were described using median $\left(25^{\text {th }}\right.$ percentile, $75^{\text {th }}$ percentile), while normally distributed data (number of glaucoma eye drops) was described using mean \pm SD. Categorical data were described in frequency and percentage. Statistical analysis was performed using IBM Statistical Package for the Social Sciences (SPSS) ${ }^{\circledR}$ Statistics Version 25. IOP was compared relative to preoperative baseline at four postoperative time points ( 1 week, 1 month, 3 months, and 6 months) using the Wilcoxon signed-rank test. The reduction in number of glaucoma eye drops was analyzed using the paired t-test. A $P$ value of $<0.01$ was considered statistically significant.

\section{Results}

A total of 34 eyes of 24 patients were included in this study. The mean follow-up period was 6 months. Table 1 summarizes the demographics, types of glaucoma, previous surgeries, and pain score. The majority of our patients (79\%) experienced mild to moderate pain during the laser procedure. Five eyes (14.7\%) underwent a second MPCPC treatment with an overall mean of 1.1 treatment sessions per eye. At the end of 6 months, three patients were lost to follow-up, leaving 21 patients (30 eyes) for the overall success rate. Figure 1 shows the flow chart for patient recruitment and follow-up.

We were able to achieve significant reduction in median IOP at all follow-up periods up to 6 months $(p<0.01)$. There were no cases of hypotony $($ IOP $<6 \mathrm{mmHg})$. Table 2 summarizes the IOP after MPCPC.

Glaucoma medications were reduced from a mean of $3.3 \pm 0.9$ (range 1-5) to 2.6 \pm 1.0 (range $0-4$ ) at 6 months $(t(26)=2.401, p=0.024)$. The reduction in number of medications was not statistically significant. Figure 2 shows the cluster graph for the number of glaucoma medications used pre- and post-procedure.

The success rate of our study was $53 \%$. Fourteen out of 30 eyes did not fulfil the criteria of a successful treatment at 6 months. The IOP remained uncontrolled within 6 months in neovascular glaucoma (3), steroid-induced glaucoma (4), primary angle-closure glaucoma (5) and primary open-angle glaucoma (4). 
Table 1. Demographics, types of glaucoma, previous surgeries, pain score

\begin{tabular}{|c|c|c|}
\hline Patients demographics & Number $(n=24)$ & Percentage (\%) \\
\hline $\begin{array}{l}\text { Age group, years (median) } \\
10 \text { to } 19 \\
20 \text { to } 29 \\
30 \text { to } 39 \\
40 \text { to } 49 \\
50 \text { to } 59 \\
60 \text { to } 69 \\
70 \text { to } 79 \\
80 \text { to } 89\end{array}$ & $\begin{array}{l}(57.5) \\
1 \\
4 \\
0 \\
4 \\
5 \\
1 \\
8 \\
1\end{array}$ & $\begin{array}{l}4 \\
17 \\
0 \\
17 \\
21 \\
4 \\
33 \\
4\end{array}$ \\
\hline $\begin{array}{l}\text { Gender } \\
\text { Male } \\
\text { Female }\end{array}$ & $\begin{array}{l}16 \\
8\end{array}$ & $\begin{array}{l}67 \\
33 \\
\end{array}$ \\
\hline Eye parameters & Number $(n=34)$ & \\
\hline $\begin{array}{l}\text { Laterality } \\
\text { Right } \\
\text { Left } \\
\text { Bilateral }\end{array}$ & $\begin{array}{l}19 \\
5 \\
10\end{array}$ & $\begin{array}{l}56 \\
15 \\
29\end{array}$ \\
\hline $\begin{array}{l}\text { Types of glaucoma } \\
\text { Neovascular glaucoma } \\
\text { Primary angle-closure glaucoma } \\
\text { Primary open-angle glaucoma } \\
\text { Axenfeld-Rieger syndrome } \\
\text { Steroid-Induced glaucoma } \\
\text { Uveitic glaucoma } \\
\text { Pseudoexfoliative glaucoma }\end{array}$ & $\begin{array}{l}7 \\
8 \\
11 \\
2 \\
4 \\
1 \\
1 \\
\end{array}$ & \begin{tabular}{|l|}
20.5 \\
23.5 \\
32.4 \\
5.9 \\
11.8 \\
2.9 \\
2.9 \\
\end{tabular} \\
\hline $\begin{array}{l}\text { Previous surgeries } \dagger \\
\text { Cataract extraction, lens implant } \\
\text { Trabeculectomy } \\
\text { Glaucoma drainage device } \\
\text { Nil }\end{array}$ & $\begin{array}{l}20 \\
13 \\
2 \\
11\end{array}$ & $\begin{array}{l}59 \\
38 \\
6 \\
32 \\
\end{array}$ \\
\hline $\begin{array}{l}\text { Pain score during procedure } \\
\text { 1-3 (mild) } \\
\text { 4-6 (moderate) } \\
\text { 7-10 (severe) }\end{array}$ & $\begin{array}{l}11 \\
16 \\
7\end{array}$ & $\begin{array}{l}32 \\
47 \\
21\end{array}$ \\
\hline
\end{tabular}

†Twelve patients underwent a combination of two previous surgeries. 


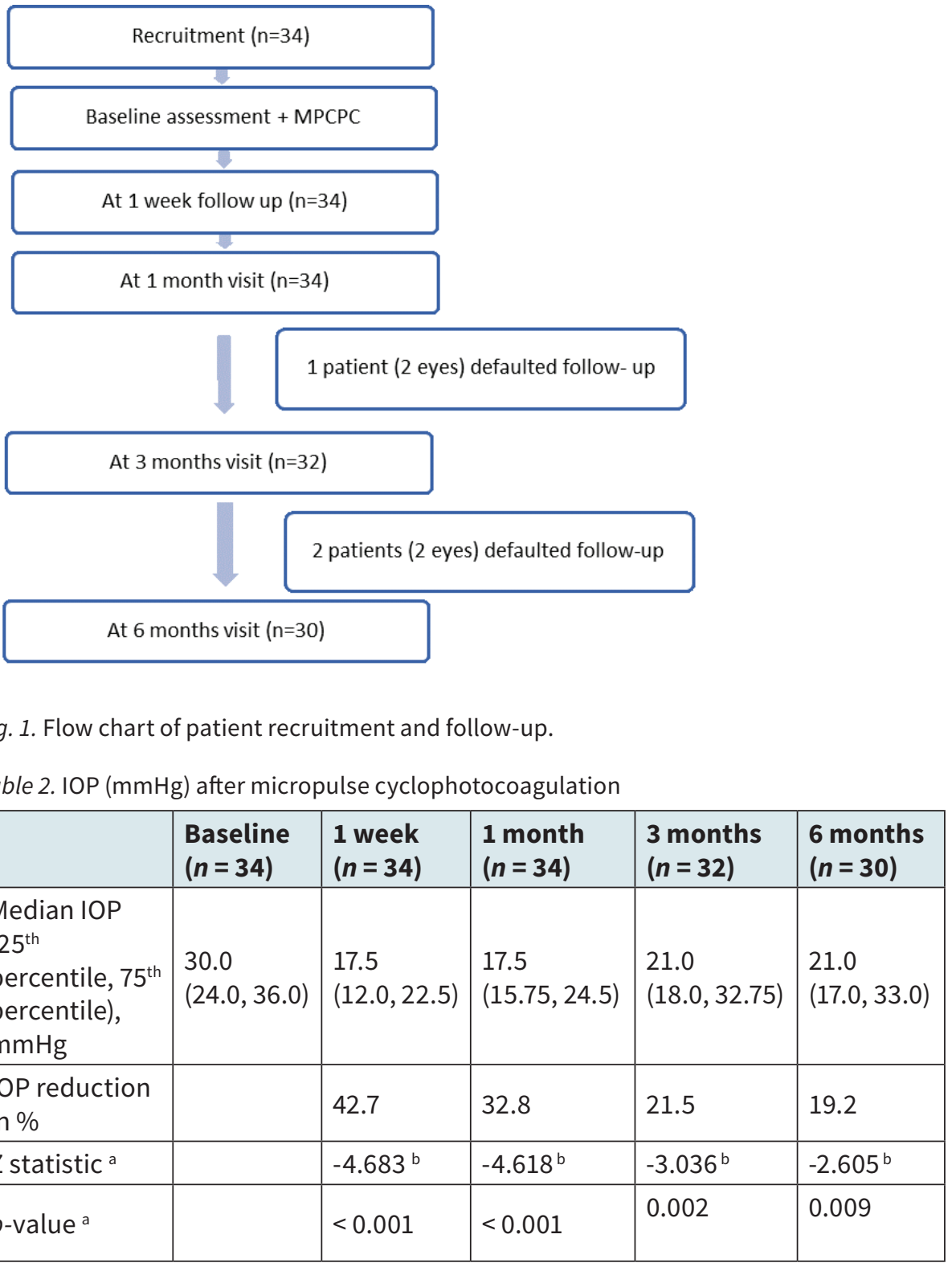

aWilcoxon Signed Ranks Test; ${ }^{\mathrm{b} B a s e d}$ on positive ranks 


\section{Reduction of eyedrops}

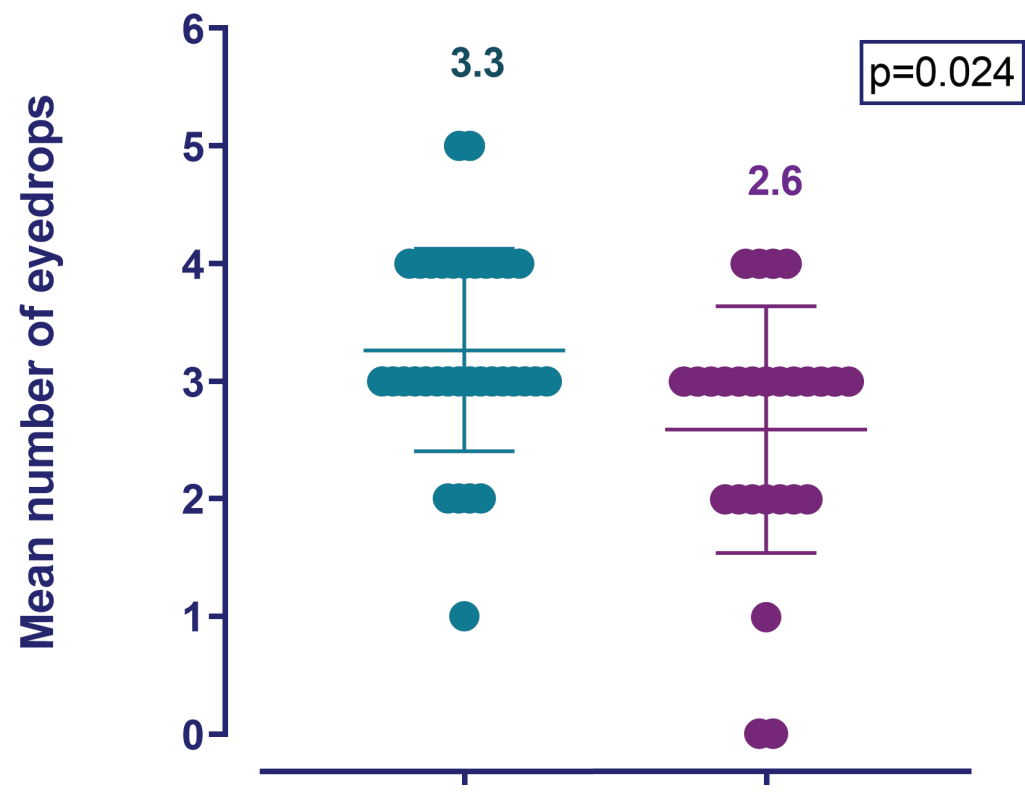

Fig. 2. Reduction in the number of glaucoma medications.

\section{Discussion}

In our study, the median IOP was significantly reduced from 30 to $21 \mathrm{mmHg}$ within 6 months $(p<0.01)$. There were no cases of hypotony. The extent of IOP-lowering effect was well sustained ( $42.7 \%$ within 1 week to $19.2 \%$ within 6 months). Our treatment success rate was $53 \%$ (16 out of 30 eyes) at 6 months. It is hypothesized that each laser pulse on the pars plana generates heat that causes ciliary body inflammation, which in turn reduces aqueous formation and enhances uveoscleral outflow. ${ }^{8}$

Most of the eyes ( 9 out of 14) that failed MPCPC treatment had previous failed filtration surgery (eight underwent trabeculectomy and one underwent tube surgery). The mean number of glaucoma medications was not significantly reduced in the final follow-up. The pain score showed that the MPCPC procedure is tolerable, as most patients complained of mild to moderate pain only.

To date, knowledge on the effectiveness and risks of MPCPC is limited due to the small number of studies, most of which are retrospective and non-comparative, with relatively limited sample sizes. ${ }^{9}$ Currently, there are no standardized parameters on micropulse technique. In our study, we utilized a relatively low 
energy level (maximum of $62.6 \mathrm{~J}$ ) with a mean of 1.1 treatment sessions per eye. We adopted our laser settings from an earlier study by Tan et al., where a $72.7 \%$ success rate was achieved at an average follow-up of 16.3 months after a mean of 1.3 treatment sessions. ${ }^{4}$ Another similar study by Williams et al. achieved a better success rate (66.1\%) within 6 months using a mean energy level of $187 \mathrm{~J}$ on 79 eyes, with only $12.6 \%$ of the eyes undergoing additional MPCPC treatment. ${ }^{10}$ Meanwhile, Sanchez et al. achieved a lower success rate (27.3\%) in their study within 6 months, utilizing energy levels within a range of 62-112 J on 22 eyes with only one session per eye. ${ }^{11}$ The total amount of energy $(\mathrm{J})$ applied appears to be among the key factors affecting the treatment outcome. Sanchez et al. carried out a literature review on nine studies to approximate the ideal MPCPC parameters for a single session treatment by comparing the efficacy and complication rates of different energy levels in J. They hypothesized that the ideal energy was around $150 \mathrm{~J}$. This energy setting gives good efficacy with few or no complications. ${ }^{12}$

Conventional TSCPC is not widely used as a primary treatment in eyes with good vision due to its complications. MPCPC, on the other hand, provides a more exquisite control of the photothermal effect by "chopping" the CW into multiple shorter laser pulses, avoiding the ciliary body tissue disruption which is routinely seen in conventional TSCPC. This explains the absence of complications like hypotony in our study. ${ }^{4,5,13}$ However, a recent cohort study on 84 eyes by Emanuel et al. showed that persistent hypotony had occurred at 3 and 6 months ( 8 and 3 eyes, respectively) after MPCPC treatment. This might be due to their longer treatment time of 319 seconds over the $360^{\circ}$ area with a mean power of $1939 \mathrm{~mW}$, which converts to a total energy of $193 \mathrm{J.}^{14}$

MPCPC has been proven to be better tolerated by patients intra- and postoperatively. ${ }^{15,16}$ This is presumably due to the fact that the micropulse laser deliver less total energy and limits the thermal damage to adjacent structures compared to TSCPC. Its favorable tolerability for patients indicates the possibility of performing this procedure in an outpatient clinic setting rather than in the operating room, thus reducing surgical burden, time, and cost.

Nevertheless, MPCPC has its own downsides. This novel laser contact probe is costly due to its strict single-use policy, which is not a cost-effective treatment modality in our setting. In addition, this procedure has no clinical evident endpoint (for example, the "pop" sound in TSCPC), making it difficult to ascertain the adequacy of treatment in each eye. ${ }^{4}$ Lastly, the laser contact probe is bulkier than the G-probe used in TSCPC, which can present a problem in treating small eye sizes. This probe is designed to aim more posterior from the limbus, which is $3 \mathrm{~mm}$ compared to the $2 \mathrm{~mm}$ of TSCPC, aiming at the pars plana of the ciliary body.

The limitations of this study reside in its design - non-comparative, retrospective case series -, small sample size, and short duration. Since MPCPC is a new treatment modality, there was no clear protocol on deciding the treatment parameters and timing of re-treatment. A clear treatment protocol is needed to 
assess the reproducibility of the results. One major confounding factor was the heterogenicity of glaucoma types in our study. Different types of glaucoma carry inconsistent response to treatment and complication rates. The study endpoint can be improved by proper stratification according to types of glaucoma. Another confounding factor may be the different ethnicities in our multiracial Malaysian population; this may need to be stratified in future studies. In our study, the primary treatment outcome was IOP, and treatment success was defined similarly to other studies. . $, 5,10,13,16$ Even though IOP remains the only modifiable factor in glaucoma, we wish to clarify that our definition of successful treatment does not equate to success in the treatment of the disease or control of disease progression, because IOP reduction may not reach the patient's specific target IOP; their glaucoma may still progress and require additional management.

In conclusion, our study showed a significant IOP-lowering effect with MPCPC and favorable patient tolerability in the treatment of refractory glaucoma. MPCPC has a promising role in the management of refractory glaucoma as a viable alternative to conventional TSCPC and surgery. Nonetheless, larger, prospective, stratified, and comparative studies are needed to determine a standardized MPCPC treatment protocol with high success and low complication rates.

\section{Acknowledgments}

We would like to thank the Director General of Health Malaysia for his permission to publish this article. The authors wish to disclose no conflicts of interest or financial interests in regards to this study.

\section{References}

1. Quigley HA, Broman AT. The number of people with glaucoma worldwide in 2010 and 2020. Br J Ophthalmol. 2006;90(3):262-267.

2. Feldman RM, el-Harazi SM, LoRusso FJ, et al. Histopathologic findings following contact transscleral semiconductor diode laser cyclophotocoagulation in a human eye. J Glaucoma. 1997;6(2):139-140.

3. Mistlberger A, Liebmann JM, Tschiderer $\mathrm{H}$, et al. Diode laser transscleral cyclophotocoagulation for refractory glaucoma. J Glaucoma. 2001;10(4):288-293.

4. Tan AM, Chockalingam M, Aquino MC, et al. Micropulse transscleral diode laser cyclophotocoagulation in the treatment of refractory glaucoma. Clin Exp Ophthalmol. 2010;38(3):266-272.

5. Aquino MC, Barton K, Tan AM, et al. Micropulse versus continuous wave transscleral diode cyclophotocoagulation in refractory glaucoma: a randomized exploratory study. Clin Exp Ophthalmol. 2015;43(1):40-46.

6. Aquino MC, Lim D, Chew PT. Micropulse P3 (MP3) Laser for Glaucoma: An Innovative Therapy. J Curr Glaucoma Pract. 2018;12(2):51-52. 
7. Boonstra AM, Stewart RE, Koke AJ, et al. Cut-Off Points for Mild, Moderate, and Severe Pain on the Numeric Rating Scale for Pain in Patients with Chronic Musculoskeletal Pain: Variability and Influence of Sex and Catastrophizing. Front Psychol. 2016;7:1466.

8. Liu GJ, Mizukawa A, Okisaka S. Mechanism of intraocular pressure decrease after contact transscleral continuous-wave Nd:YAG laser cyclophotocoagulation. Ophthalmic Res. 1994;26(2):65-79.

9. Ma A, Yu SWY, Wong JKW. Micropulse laser for the treatment of glaucoma: A literature review. Surv Ophthalmol. 2019;64(4):486-497.

10. Williams AL, Moster MR, Rahmatnejad K, et al. Clinical Efficacy and Safety Profile of Micropulse Transscleral Cyclophotocoagulation in Refractory Glaucoma. J Glaucoma. 2018;27(5):445-449.

11. Sanchez FG, Lerner F, Sampaolesi J, et al. Efficacy and Safety of Micropulse(R) Transscleral Cyclophotocoagulation in Glaucoma. Arch Soc Esp Oftalmol. 2018;93(12):573-579.

12. Sanchez FG, Peirano-Bonomi JC, Grippo TM. Micropulse Transscleral Cyclophotocoagulation: A Hypothesis for the Ideal Parameters. Med Hypothesis Discov Innov Ophthalmol. 2018;7(3):94-100.

13. Kuchar S, Moster MR, Reamer CB, et al. Treatment outcomes of micropulse transscleral cyclophotocoagulation in advanced glaucoma. Lasers Med Sci. 2016;31(2):393-396.

14. Emanuel ME, Grover DS, Fellman RL, et al. Micropulse Cyclophotocoagulation: Initial Results in Refractory Glaucoma. J Glaucoma. 2017;26(8):726-729.

15. Friberg TR, Venkatesh S. Alteration of pulse configuration affects the pain response during diode laser photocoagulation. Lasers Surg Med. 1995;16(4):380-383.

16. Yelenskiy A, Gillette TB, Arosemena A, et al. Patient Outcomes Following Micropulse Transscleral Cyclophotocoagulation: Intermediate-term Results. J Glaucoma. 2018;27(10):920-925. 